Plant Production Science

http:/www.journals.zu.edu.eg/journalDisplay.aspx?Journalld=1\&queryType=Master

\title{
GENE ACTION AND HETEROSIS OF MUSKMELON
}

\author{
Walled H.A. Hassan ${ }^{1}$, A.A. Gad ${ }^{2}$, M.M. Abd El-Salam ${ }^{1}$ and H.E.M. Ismail ${ }^{2 *}$ \\ 1. Veg. Breed. Res. Dept., Hort. Res. Inst., ARC, Giza, Egypt \\ 2. Hort. Dept., Fac. Agric., Zagazig Univ., Egypt
}

Received: 01/10/2018; Accepted: 01/11/2018

\begin{abstract}
Six parental genotypes namely "673 $\left(\mathrm{P}_{1}\right)$, 3M-637-D $\left(\mathrm{P}_{2}\right)$, 3M-673-EB $\left(\mathrm{P}_{3}\right)$, 86E2143 $\left(\mathrm{P}_{4}\right), 86 \mathrm{E} 2147\left(\mathrm{P}_{5}\right)$ and WA20 $\left(\mathrm{P}_{6}\right)$ " representing wide range of variability in most of the studied traits, were employed and crossed in half diallel fashion. This investigation was carried out at the Experimental Farm of Ismailia Agriculture Research station, Ismailia Governorate, Egypt, during the three summer seasons of 2015, 2016 and 2017, to study the important economical traits of muskmelon as fruit width, fruit length, flesh thickness, cavity diameter, total soluble solids, ascorbic acid content, carotenoids content, fruit weight, total yield/vine and fruit number/vine. A greater ratio of GCA/SCA than unity was detected for most studied traits, revealing that the inheritance of these traits was mainly controlled by additive gene effects. On the contrary, both TSS and ascorbic acid content traits, nonadditive type of gene action seemed to be more prevalent. The maximum significant MP heterosis in desirable direction (112.4\%) was recorded for ascorbic acid followed by total yield/vine $(101.0 \%)$, number of fruits per vine $(100 \%)$, TSS $(65.3 \%)$, flesh thickness $(62.1 \%)$, fruit weight $(59.8 \%)$ and fruit length (53.6\%). Heterobeltiasis (over the best parent better, BP) was observed and the maximum significant manifestation was orderd as: Ascorbic acid (108\%), number of fruits per vine $(69.4 \%)$, both TSS $(\%)$ and cavity diameter $(58.8 \%)$ and total yield per vine $(49.8 \%)$. The cross 3M-637-D $\left(\mathrm{P}_{2}\right)$ $\mathrm{x} 86 \mathrm{E} 2143\left(\mathrm{P}_{4}\right)$ was derived from low $\mathrm{x}$ high general combiner parents for total yield/ vine and exhibited the highest mean yield, highest heterosis, highest SCA effects for yield. It showed also, significant or highly significant desirable SCA effects for eight important traits.
\end{abstract}

Key words: Cucumis melo var. reticulalus, combining ability, general combining ability, specific combining ability, heterosis and heterobeltiosis

\section{INTRODUCTION}

Although the muskmelon $(2 \mathrm{n}=24)$ is an important crop in Egypt, however, it suffers several problems, the most important being the rise of imported seeds. A research is an attempt to provide appropriate local hybrids with good price and high quality. Many studies were done in this connection by several researchers, such as (Feyzian et al., 2009; Choudhary and Pandey, 2010; Lohani, 2013) on muskmelon through studying combining ability effects and heterosis for many economic traits. In addition, several authors detected additive and nonadditive gene effect in the genetic control of the average fruit weight and TSS traits (Singh and

\footnotetext{
* Corresponding author: Tel. : +201005133426
}

E-mail address: hanyeldewah7@gmail.com
Randhawa, 1990; Monforte et al., 2004; Lohani, 2013; Tak, 2017) on muskmelon. The quality, high yield, fruit shape and size were the important objectives of melon breeding programs (Zalapa et al., 2006). The general combining ability (GCA) allows the identification of parents with higher frequency of favorable alleles, while the SCA indicates the most promising hybrid combinations (Ferreira et al., 2002; Valerio et al., 2009).

Therefore, the objectives of the present study were to estimate the magnitude of heterosis as well as general and specific combining abilities for yield and its quality traits in a half diallel set to recognize desirable parents and their cross combinations as genetic resources for improving 
these important traits and to identify suitable material to use it in muskmelon breeding. It is hoped that the present study may help the breeder to produce new hybrid varieties of melon to have higher yielding potentiality.

\section{MATERIALS AND METHODS}

According to data obtained from the evaluated numerous muskmelon inbred lines, developed and introduced from different sources (Table 1) having sufficient variability, in the end of the 2014 summer season, the six best inbred lines based on fruit shape, flesh color, fruit length and width and average fruit weight as main target were used as parents to produce a $6 \times 6$ half diallel crosses at the Experimental Farm, Ismailia Agriculture Research Station during the three summer seasons of 2015, 2016 and 2017 to study heterosis, general and specific combining ability with diallel cross system without reciprocals for some important economic traits.

Seeds of the inbred lines were sown during the summer season of 2015 to produce self progeny and were sown on summer season of 2016 to produce the fifteen $F_{1}$ hybrids by a half diallel mating design, (Briggs and Knowles, 1967). Parents and their fifteen hybrids were evaluated on March, 2017 in randomized complete block (RCBD) design with three replications. Each replicate contained 21 experimental units or plots ( 6 parents and $15 \mathrm{~F}_{1}$ ). Each plot was presented by a single 1 terrace, $1.5 \mathrm{~m}$ width and $10 \mathrm{~m}$ length (experimental plot area $=15 \mathrm{~m}^{2}$ ). The terraces were spaced at $1.5 \mathrm{~m}$ and the plants at $0.5 \mathrm{~m}$. All data recorded on five plants from each plot for the all genotypes. To raise a good and healthy crop, all agricultural practices carried out as recommended by the Egyptian Agriculture Ministry for muskmelon cultivation in sandy soil with drip irrigation system.

\section{Observations Recorded}

1. Fruit width $(\mathrm{FW}), \mathrm{cm}$.

2. Fruit length (FL), cm.

3. Flesh thickness (FT), cm.

4. Cavity diameter (CD), $\mathrm{cm}$.

5. Total soluble solids content (TSS) (\%).

6. Ascorbic acid contain (A), as $\mathrm{mg} / 100 \mathrm{~g}$ was evaluated as described by Sadasivam and Manickam (1996).
7. Carotenoids contain (CC), as $\mathrm{mg} / 100 \mathrm{~g}$ in the fruit was extracted by methods reported by Robinson and Britz (2000) after adding a trace from sodium carbonate, then total carotenoids were determined spectrophotometrically (Lichtenthaler and Wellburn, 1985).

8. Fruit weight (FWE), Kg.

9. Total yield/vine (TY), Kg.

10. Fruit number per vine (F No./vine).

\section{Statistical Analysis}

\section{Analysis of variance}

Variance for randomized complete block design (RCBD) was used to test the significance of differences among the genotypes, including crosses and parents (Snedecor and Cochran, 1967).

\section{Types of heterosis}

Two types of heterosis [Relative heterosis (MP) and heterobeltiosis (BP)] were estimated and expressed as percentages: Relative heterosis and heterobeltiosis were estimated as the deviation of $F_{1}$ mean over the mid-parents (MP) and high parent (HP) in each cross, respectively (Bhatt, 1971).

$\mathrm{BP}=\frac{\mathrm{F}_{1}-\mathrm{BP}}{\mathrm{HP}} \times 100$
$\mathrm{MP}=\frac{\mathrm{F}_{1}-\mathrm{MP}}{\mathrm{MP}} \times 100$

Analysis of variance for combining ability

General combining ability (GCA) and specific combining ability (SCA) were estimated by following Model-I, Method II of Griffing (1956) using Diallel software program.

\section{RESULTS AND DISCUSSION}

\section{The Analysis of Variance}

The analysis of variance showed highly significant differences between the parents and their hybrids for all the traits in this study (Table 2). These results indicated that, there was substantial genotypic variation among the genotypes. In Table 3, the mean squares due to general and specific combining abilities were 
Zagazig J. Agric. Res., Vol. 45 No. (6A) 2018

Table 1. Pedigree and origin of the six inbred lines of muskmelon studied

\begin{tabular}{|c|c|c|c|c|c|c|}
\hline Genotype & $\begin{array}{l}\text { Fruit } \\
\text { shape }\end{array}$ & $\begin{array}{l}\text { Fruit length } \\
\text { \& width (cm) }\end{array}$ & $\begin{array}{l}\text { Avg. fruit } \\
\text { weight (g) }\end{array}$ & $\begin{array}{l}\text { Flesh } \\
\text { color }\end{array}$ & Source & Picture \\
\hline $\begin{array}{l}673 \\
(P 1)\end{array}$ & Spherical & $14.10 \& 13.75$ & 1016.67 & $\begin{array}{l}\text { White to } \\
\text { Green }\end{array}$ & IPGR & \\
\hline $\begin{array}{l}\text { 3M-637-D } \\
\text { (P2) }\end{array}$ & Oblong & $10.70 \& 10.90$ & 546.67 & $\begin{array}{c}\text { White to } \\
\text { Green }\end{array}$ & HRI & \\
\hline $\begin{array}{l}\text { 3M-673- } \\
\text { EB (P3) }\end{array}$ & Cylindrical & $23.67 \& 15.42$ & 1850.00 & Orange & HRI & \\
\hline $\begin{array}{c}\text { 86E2143 } \\
\text { (P4) }\end{array}$ & Spherical & $17.22 \& 16.07$ & 1660.00 & White & IPGR & \\
\hline $\begin{array}{c}\text { 86E2147 } \\
\text { (P5) }\end{array}$ & Spherical & $12.50 \& 13.75$ & 1250.00 & $\begin{array}{l}\text { White to } \\
\text { Green }\end{array}$ & IPGR & \\
\hline $\begin{array}{c}\text { WA20 } \\
\text { (P6) }\end{array}$ & Spherical & $14.57 \& 14.18$ & 750.00 & Green & HRI & \\
\hline
\end{tabular}

$\overline{\text { IPGR = Institute for Plant Genetic Resources (Sadovo Bulgaria), HRI = Department of Vegetables Breeding Horticulture }}$ Research Institute, Giza, Egypt

Table 2. Mean squares from analysis of variance for some economic traits in a $6 \times 6$ half-diallel cross in muskmelon

\begin{tabular}{cccccccccccc}
\hline SOV & DF & FW & FL & FT & CD & TSS & AAC & CC & FWE & TY/Vine & F. No./Vine \\
\hline Rep. & 2 & 0.52 & 0.10 & 0.04 & 0.05 & 0.83 & 2.54 & 3.00 & 13.32 & 659.01 & 0.02 \\
Treat. & 20 & $10.54^{* *}$ & $39.32^{* *}$ & $2.88^{* *}$ & $2.54^{* *}$ & $11.51^{* *}$ & $86.09^{* *}$ & $28.27^{* *}$ & $463.54^{* *}$ & $\begin{array}{c}10039.45^{*} \\
*\end{array}$ & $1.15^{*}$ \\
Error & 40 & 0.12 & 0.18 & 0.03 & 0.02 & 0.160 & 1.85 & 0.61 & 9.95 & 881.53 & 0.001
\end{tabular}

$\overline{\mathrm{FW}}=$ Fruit width, $\mathrm{FL}=$ Fruit length, $\mathrm{FT}=$ Flesh thickness, $\mathrm{C} . \mathrm{D}=$ Cavity diameter, $\mathrm{TSS}=$ Total soluble solids, $\mathrm{AAC}=\mathrm{Ascorbic}$ acid contain, $\mathrm{C} . \mathrm{C}=$ Carotenoids contain, $\mathrm{F} . \mathrm{WE}=$ Fruit weight, $\mathrm{TY}=$ Total yield/ vine and $\mathrm{F}$. No. $=$ Fruit number/ vine.

*** Significant at $5 \%$ and $1 \%$ levels of probability, respectively. 
Table 3. Mean squares from analysis of variance for combining ability and GCA/SCA ratio for some economic traits in a $6 \times 6$ half-diallel cross in muskmelon

\begin{tabular}{cccccccccccc}
\hline SOV & DF & FW & FL & FT & CD & TSS & AAC & CC & F.WE & TY/Vine & F. No./Vine \\
\hline GCA & 5 & $4.24^{*}$ & $24.69^{* *}$ & $1.14^{* *}$ & $1.10^{* *}$ & $0.58^{* *}$ & $22.51^{* *}$ & $13.56^{* *}$ & $221.40^{* *}$ & $7458.30^{* *}$ & $2.76^{* *}$ \\
SCA & 15 & $3.98^{*}$ & $10.94^{* *}$ & $0.90^{* *}$ & $0.76^{* *}$ & $4.92^{* *}$ & $30.76^{*}$ & $8.043^{* *}$ & $132.21^{* *}$ & $1975.88^{* *}$ & $0.76^{*}$ \\
Error & 40 & 0.06 & 0.07 & 0.01 & 0.01 & 0.05 & 0.62 & 0.203 & 3.32 & 293.84 & 0.17 \\
GCA/SCA & 1.06 & 2.27 & 1.27 & 1.44 & 0.12 & 0.73 & 1.69 & 1.67 & 3.77 & 3.36 \\
\hline
\end{tabular}

$\overline{\mathrm{FW}}=$ Fruit width, $\mathrm{FL}=$ Fruit length, $\mathrm{FT}=$ Flesh thickness, $\mathrm{C} . \mathrm{D}=$ Cavity diameter, $\mathrm{TSS}=$ Total soluble solids, $\mathrm{AAC}=\mathrm{Ascorbic}$ acid contain, $\mathrm{CC}=$ Carotienoids contain, $\mathrm{F} . \mathrm{WE}=$ Fruit weight, $\mathrm{TY}=$ Total yield/ vine and $\mathrm{F} . \mathrm{No}=$ Fruit number/ vine.

*,** Significant at $5 \%$ and $1 \%$ levels of probability, respectively.

significant for all studied traits, this result suggesting the presence of both additive and non-additive gene effects in the expression of all traits under studying. The magnitude of general combining ability variance was higher than that of the specific one for all studied traits except both total soluble solids (TSS) and ascorbic acid contents, indicating that additive gene effects playing an important role in the expression of these traits, the ratio GCA/SCA, which exceeded one substantiated this finding. However, although additive gene effects made the greatest contribution to variability of the majority of traits, the role of dominance and overdominance in the genetic system of control of yield components was also considerable. Lohani (2013) and Tak (2017) reported similar results.

\section{General and Specific Combining Ability Effects}

Estimates of GCA effects of individual parental genotypes in the $F_{1}$ generation (Table 4) were found to be significant or highly significant for the most studied traits. In this regard, $\mathrm{P}_{4}$ was a good combiner for all trait except TSS and cavity diameter, whereas $\mathrm{P}_{1}, \mathrm{P}_{2}$ and $\mathrm{P}_{5}$ were the best general combiner for cavity diameter trait, $\mathrm{P}_{6}, \mathrm{P}_{1}$ and $\mathrm{P}_{3}$ showed the highest value for fruits number trait (Table 4), while $\mathrm{P}_{5}$ appeared to be good general combiner for each of TSS, cavity diameter and ascorbic acid and fruit weight. Similar results were observed by Choudhary and Pandey (2010).

The potentiality of crossing between specific parents were detected by estimating specific combining ability (SCA) effects of each $\mathrm{F}_{1}$ cross combination for all studied traits (Table 5). 5 out of 15 crosses exhibited significant positive SCA effects for total yield/vine. Four out of these five crosses namely: $\left(\mathrm{P}_{1} \times \mathrm{P}_{2}\right),\left(\mathrm{P}_{1} \times \mathrm{P}_{5}\right),\left(\mathrm{P}_{2} \times \mathrm{P}_{4}\right)$ and $\left(\mathrm{P}_{3} \times \mathrm{P}_{6}\right)$ exhibited significant desirable positive SCA for fruit width, fruit length and fruit thickness. Three out of these four crosses $\left(\mathrm{P}_{1} \mathrm{x}\right.$ $\mathrm{P}_{2}, \mathrm{P}_{2} \times \mathrm{P}_{4}$ and $\mathrm{P}_{3} \times \mathrm{P}_{6}$ ) along with the best cross $\left(\mathrm{P}_{5} \times \mathrm{P}_{6}\right)$ exhibited significant desirable positive SCA for ascorbic acid content. Three out of the four later crosses namely: $\left(\mathrm{P}_{2} \times \mathrm{P}_{4}\right),\left(\mathrm{P}_{3} \times \mathrm{P}_{6}\right)$ and $\left(\mathrm{P}_{5} \times \mathrm{P}_{6}\right)$ exhibited significant desirable positive or negative SCA effects for both of cavity diameter and carotenoids, as well as the superiority of $\left(\mathrm{P}_{2} \times \mathrm{P}_{4}\right)$ and $\left(\mathrm{P}_{5} \times \mathrm{P}_{6}\right)$ for SCA effect of TSS indicating the possibility of combine both high yield and good quality characters. The five cross combinations, which exhibited significant positive SCA for yield/ vine, were also combined significant/highly significant desirable negative or positive (due to the breeder"s point of view) SCA effects for two or more important yield components particularly fruit width, fruit length, fruit thickness, number of fruits, fruit weight, cavity diameter, TSS.. etc. These results are in harmony with Monforte $\boldsymbol{e t}$ al. (2004).

Furthermore, comparing the performance of the cross combinations on the basis of total yield per vine and highest desirable heterotic response for yield as well as SCA effects of crosses along with GCA effects of the parents were done to the most important crosses. The best crosses, which classified on the basis of these parameters are shown in Table 6 . Three out of these 7 best crosses were derived from $\mathrm{P}_{4}(86 \mathrm{E} 2143)$ as male 
Zagazig J. Agric. Res., Vol. 45 No. (6A) 2018

1957

Table 4. Estimates of general combining ability (GCA) of six muskmelon-inbred lines for some economical traits

\begin{tabular}{lccccccc}
\hline Trait & P1 & P2 & P3 & P4 & P5 & P6 & gca(j) \\
\hline Fruit width & & & & & & & \\
Fruit length & $-0.44^{* *}$ & $-0.69^{* *}$ & $0.32^{* *}$ & $1.20^{* *}$ & $-0.61^{* *}$ & $0.22^{* *}$ & 0.10 \\
Flash thickness & $-0.53^{* *}$ & $-0.67^{* *}$ & $-1.20^{* *}$ & $3.54^{* *}$ & $-0.82^{* *}$ & $-0.33^{* *}$ & 0.08 \\
Cavity diameter & $-0.05^{\mathrm{ns}}$ & $-0.18^{* *}$ & $-0.17^{* *}$ & $0.55^{* *}$ & $-0.25^{* *}$ & $0.09^{* *}$ & 0.03 \\
TSS & $-0.34^{* *}$ & $-0.33^{* *}$ & $0.66^{* *}$ & $0.10^{* *}$ & $-0.12^{* *}$ & -0.03 & 0.04 \\
Ascorbic acid contain & $-2.39^{* *}$ & $-1.87^{* *}$ & $0.68^{* *}$ & $1.37^{* *}$ & $1.30^{* *}$ & $0.92^{* *}$ & 0.253 \\
Carotienoids contain & $0.50^{* *}$ & $-0.77^{* *}$ & $-1.01^{* *}$ & $2.27^{* *}$ & 0.19 & $-1.19^{* *}$ & 0.1456 \\
Fruit weight & $-61.53^{* *}$ & $-109.65^{* *}$ & $-6.74 \mathrm{~ns}$ & $288.68^{* *}$ & $15.35 \mathrm{~ns}$ & $-126.11^{* *}$ & 15.32 \\
Total yield/vine & 33.89 & $-578.40^{* *}$ & $-428.40^{* *}$ & $1933.26^{* *}$ & $-685.90^{* *}$ & $-274.44^{*}$ & 114.95 \\
Fruit No./vine & $0.28^{*}$ & $-0.06^{\mathrm{ns}}$ & $-0.26^{*}$ & $0.15^{\mathrm{ns}}$ & $-0.39^{* *}$ & $0.28^{*}$ & 0.13 \\
\hline
\end{tabular}

Table 5. Estimates of specific combining ability (SCA) effects of fifteen muskmelon $F_{1}$ hybrids for some economical traits

\begin{tabular}{|c|c|c|c|c|c|c|c|c|c|c|}
\hline$\overline{\text { Crosses }}$ & $\overline{F W}$ & $\overline{F L}$ & FT & $\overline{C D}$ & TSS & $\overline{\mathrm{AAC}}$ & $\mathrm{CC}$ & FWE & TY & FN \\
\hline$\overline{1 \times \mathbf{P 2}}$ & $1.86^{* *}$ & $1.49^{* *}$ & $0.60 * *$ & $0.65^{* *}$ & -0.04 & $0.91^{*}$ & $-0.22^{\mathrm{ns}}$ & $103.01^{*}$ & $1324.91 * *$ & $0.90^{\mathrm{ns}}$ \\
\hline$\times \mathbf{P 3}$ & $0.61 * *$ & $2.22 * *$ & 0.02 & $0.56^{* *}$ & $3.44 * *$ & $3.49^{* *}$ & $0.97 * *$ & $316.76^{* *}$ & $-25.09^{\mathrm{ns}}$ & $-1.22 *$ \\
\hline P1 $\times$ P4 & $-0.67 * *$ & $-1.62 * *$ & $-0.90 * *$ & $1.13 * *$ & $-0.98 * *$ & $-2.02 * *$ & $4.41 * *$ & $221.34 * *$ & $529.91^{\text {ns }}$ & $-0.30^{\mathrm{ns}}$ \\
\hline$\times P 5$ & 1.37 & 1.24 & 0.70 & $-0.03^{\text {ns }}$ & $0.17^{\mathrm{ns}}$ & -0. & $-0.09^{\text {ns }}$ & -43 & 123 & $1.90 * *$ \\
\hline P1 $\times P 6$ & $-2.39 * *$ & $-2.09 * *$ & $-0.84 * *$ & $-0.71 * *$ & $-0.25^{\mathrm{ns}}$ & $1.58^{* *}$ & $1.37 * *$ & $-212.20 * *$ & $-1787.38^{* *}$ & $-0.43^{\text {ns }}$ \\
\hline (1) & $-0.47^{*}$ & $-1.45^{* *}$ & -0.08 & $-0.31 *$ & $2.23 * *$ & $-3.68^{* *}$ & 0.03 & $-261.79 * *$ & $-1919.46^{* *}$ & $-0.89^{\mathrm{ns}}$ \\
\hline P2 $\times P 4$ & $2.84 * *$ & $7.86^{* *}$ & $1.96^{* *}$ & $-1.08 * *$ & $1.48 * *$ & $5.88 * *$ & $2.62 * *$ & $369.46^{* *}$ & $4475.54 * *$ & $1.36^{*}$ \\
\hline $2 \times P 5$ & $-1.54 * *$ & $-0.95 * *$ & $-0.77 * *$ & $-0.01^{\mathrm{ns}}$ & $-0.38^{\mathrm{ns}}$ & $3.28 * *$ & $1.75^{* *}$ & 442.8 & $261.37^{\mathrm{ns}}$ & $-1.43 *$ \\
\hline $\mathrm{P} 2 \times \mathrm{P} 6$ & $1.63 * *$ & $0.23^{\mathrm{ns}}$ & $0.69 * *$ & $0.25^{\mathrm{ns}}$ & $-0.79 * *$ & $0.86^{*}$ & $0.74 * *$ & $84.26^{*}$ & $-350.09^{\mathrm{ns}}$ & $-0.43^{\mathrm{ns}}$ \\
\hline P3 $\times$ P4 & 0.23 & $-0.68 * *$ & -0.18 & $0.59 * *$ & $-0.71 * *$ & $4.51 * *$ & $0.83 * *$ & $-100.12 *$ & $-1757.80^{* *}$ & $-0.76^{\text {ns }}$ \\
\hline P3 $\times$ P5 & $-4.27 * *$ & $-7.61 * *$ & $-1.98 * *$ & $-0.13^{\mathrm{ns}}$ & $-0.54 *$ & $3.9^{* *}$ & 0.13 & $-866.79 * *$ & $-3441.13 * *$ & $2.24 * *$ \\
\hline P3 $\times$ P6 & $1.01 * *$ & $4.25^{* *}$ & $0.88 * *$ & $-0.74 * *$ & 0.19 & $4.71 * *$ & $1.35^{* *}$ & 48.01 & $2449.91 * *$ & $0.78^{\mathrm{ns}}$ \\
\hline P4 $\times$ P5 & $-3.60 * *$ & $-4.56^{* *}$ & $-0.87 * *$ & $-1.87 * *$ & $3.52 * *$ & $2.99 * *$ & $0.61 * *$ & $-255.54 * *$ & $-1733.63 * *$ & $-0.30^{\text {ns }}$ \\
\hline 6 & 0.37 & $-2.65^{* *}$ & $-0.21^{\mathrm{ns}}$ & $0.79 * *$ & $-1.73 * *$ & $1.96^{* *}$ & $2.94 * *$ & $69.26^{\mathrm{ns}}$ & $471.58^{\mathrm{ns}}$ & $0.36^{\mathrm{ns}}$ \\
\hline $\mathrm{P5} \times \mathrm{P6}$ & $0.35^{\mathrm{ns}}$ & $1.37 * *$ & $0.39^{*}$ & $-0.43 * *$ & $3.58^{* *}$ & $7.89 * *$ & $-0.01^{\mathrm{ns}}$ & $275.92 * *$ & $1524.08 * *$ & $-0.10^{\mathrm{ns}}$ \\
\hline $\mathrm{CSD}_{0.05}$ & 0.40 & 0.28 & 0.30 & 0.30 & 0.47 & 0.10 & 0.41 & 80.02 & 714.01 & 1.17 \\
\hline $\mathbf{L S D}_{0.01}$ & 0.56 & 0.38 & 0.41 & 0.41 & 0.65 & 0.97 & 0.56 & 110.66 & 987.42 & 1.62 \\
\hline
\end{tabular}


Table 6. The best crosses chosen for yield on the basis of heterosis responses and SCA along with GCA effects of the involved parents

\begin{tabular}{|c|c|c|c|c|c|c|c|c|}
\hline \multirow[t]{2}{*}{ Crosses } & \multirow{2}{*}{$\begin{array}{c}\text { Mean } \\
\text { yield/vine } \\
\text { (kg) }\end{array}$} & \multicolumn{2}{|c|}{ Heterosis } & \multirow[t]{2}{*}{ SCA } & \multicolumn{2}{|c|}{ GCA } & \multicolumn{2}{|c|}{$\begin{array}{l}\text { Desirable significant } \\
\text { (for other traits) }\end{array}$} \\
\hline & & MP & HP & & $\mathbf{1}^{\text {st }} \mathrm{p}$ & $2^{\text {nd }} p$ & MP Heterosis & SCA \\
\hline $\mathrm{P}_{2} \times \mathrm{P}_{4}$ & 11.783 & $100.97^{* *}$ & $33.50 * *$ & $4475.5 * *$ & $-578.4 * *$ & $1933.26^{* *}$ & All & All \\
\hline $\mathrm{P}_{1} \times \mathrm{P}_{4}$ & 8.450 & $18.93^{* *}$ & -4.27 & 529.9 & 33.89 & $1933.26^{* *}$ & $\mathrm{f}, \mathrm{g}, \mathrm{h}$ & $\mathrm{g}, \mathrm{h}$ \\
\hline $\mathrm{P}_{4} \times \mathrm{P}_{6}$ & 8.083 & $23.63 * *$ & $-8.42 * *$ & 471.6 & $1933.26 * *$ & $-274.44 * *$ & $f, g, h, i$ & $\mathrm{a}, \mathrm{f}, \mathrm{g}, \mathrm{h}$ \\
\hline $\mathrm{P}_{3} \times \mathrm{P}_{6}$ & 7.700 & $48.31 * *$ & $25.54 * *$ & $2449.9 * *$ & $-428.4 *$ & $-274.44 * *$ & All except h & All except e,h \\
\hline $\mathrm{P}_{1} \times \mathrm{P}_{2}$ & 6.733 & $62.58^{* *}$ & $25.08^{* *}$ & $1324.9 * *$ & 33.89 & $-578.4 * *$ & All & All except d,e,g \\
\hline $\mathrm{P}_{1} \times \mathrm{P}_{5}$ & 6.533 & $34.25^{* *}$ & $21.36^{* *}$ & $1232.4 * *$ & 33.89 & $-685.9 * *$ & All except a,b,c,h & $\mathrm{a}, \mathrm{b}, \mathrm{c}, \mathrm{i}$ \\
\hline $\mathrm{P}_{5} \times \mathrm{P}_{6}$ & 6.516 & $51.55^{* *}$ & $49.81 * *$ & $1524.1 * *$ & $-685.9 * *$ & $-274.44 * *$ & All except a,b,c & All except g,i \\
\hline
\end{tabular}

$\mathrm{FW}=$ Fruit width, $\mathrm{FL}=$ Fruit length, $\mathrm{FT}=$ Flesh thickness, $\mathrm{C} . \mathrm{D}=$ Cavity diameter, $\mathrm{TSS}=$ Total soluble solids, $\mathrm{AAC}=\mathrm{Ascorbic}$ acid contain, $\mathrm{CC}=$ Carotienoids contain, $\mathrm{F} . \mathrm{WE}=$ Fruit weight, $\mathrm{TY}=$ Total yield/ vine and $\mathrm{F} . \mathrm{No}=$ Fruit number/ vine..

or female parent that was above classified as a good general combiner in desirable trend for all studied traits. Therefore, this parent (86E2143) could be used as promising progenitors for abovementioned traits either for heterosis breeding or in genetic improvements by means of selection in segregating generations. The first cross (3M-637-D x 86E2143) was derived from poor $\mathrm{x}$ good general combiner parents for yield/vine and exhibited the highest mean yield, highest desirable heterosis (for yield and all other traits), similar results were reported by Feyzian et al. (2009) and highest desirable SCA effects (for yield and all other traits).

Again, these results reveal that this cross can be considered the best combination among the 15 crosses evaluated in the present work. The second $(673 \times 86 \mathrm{E} 2143)$ and third (86E2143 x WA20) yielded crosses showed high SCA values involve one only good combiner, while all other 4-best crosses namely (3M-673-EB x WA20), (673 x 3M-637-D), (673 x 86E2147) and (86E2147 x WA20) were derived from poor $\mathrm{x}$ poor general combiner parents, and each showed high mean yield/vine, highly significant desirable heterosis and highly significant SCA effects for at least two important yield and quality contributing traits. However, parents with high GCA effects did not necessarily produce hybrid with high SCA effects and vice versa. In most of the best crosses showing high
SCA involve one only good combiner, such combinations would throw out desirable transgressive segregates provided that the additive genetic system present in the good combiner and complementary and epistatic effects present in the crosses, act in the same direction to reduce undesirable plant characteristics and maximize the character in view (Habeeb, 1998). Results revealed that the abovementioned cross combinations might be of prime importance in breeding program for traditional breeding procedures for yield or some of its important components through selection in the segregating generations to exploit a fixable additive gene action which is due to the significance of GCA effects. Also, it could be used for the exploitation of nonadditive gene effects, that related to the significance of SCA effects, in heterosis breeding. So, the characters like TSS and ascorbic acid, which are mainly controlled by non-additive gene effects, could be exploit by heterosis breeding. These results are similary with those of Chalha and Nandpuri (1980) and Singh and Randhawa (1990).

\section{Types of Heterosis}

Heterosis values for $15 F_{1}$ hybrids of fruit width were given in Table 7. A wide range of heterosis values was existed namely: from $-32.05 \%$ to $26.79 \%$ over to mid-parent and from 
$-34.25 \%$ to $15.46 \%$ over to high respective parents. Desirable positive MP heterosis was observed in $4 \mathrm{~F}_{1}$ crosses, while three $\mathrm{F}_{1}$ crosses showed HP desirable heterosis. The heterotic expression for fruit length varied with values ranging from $-41.13 \%$ to $53.62 \%$ for both types of heterosis with 5 and 4 crosses exhibited significant positive MP and HP heterosis, respectively. The magnitude of significant positive heterosis for flesh thickness (Table 7) was up to $62.06 \%$ over MP and $20.8 \%$ over HP.

Heterosis for cavity diameter (in the same Table) varied from $-41.59 \%$ to $58.81 \%$ when all the two types of heterosis are considered. Desirable negative MP heterosis was observed in nine $F_{1}$ crosses and four one exhibited desirable HP heterosis. On the other hand, the largest number of crosses having desirable positive MP and BP heterosis was observed in carotenoids, ascorbic acid and TSS as 15, 14 and 11 crosses exhibited up to $39.09 \%, 112.36 \%$ and $65.31 \%$ desirable MP heterosis, respectively and 14,13 and 9 crosses showed up to $35.93 \%$, $107.98 \%$ and $58.82 \%$ heterobeltiosis for the three traits, respectively. Out of 15 studied crosses, 8 over MP and 5 over BP showed significant positive heterosis for fruit weight.

Heterosis of total yield per vine expressed as the percentage deviation of $\mathrm{F}_{1}$ mean performance from MP and HP are presented in Table 7. Estimates of the both types of heterosis varied between $-50.65 \%$ and $100.97 \%$. Nine out of the 15 crosses showed significant positive MP heterosis, while 7 crosses exhibited HP heterosis. Significant positive heterosis for fruit number per vine up to $100 \%$ over MP and $69.44 \%$ over HP was recorded. Out of all studied crosses, 8 over MP and 6 over HP showed significant positive heterosis for this trait. Similar results were reported by Choudhary and Pandey (2010).

Table 7. Range of heterosis (\%) for studied traits and number of superior crosses showing significant desirable heterosis

\begin{tabular}{lcccc}
\hline \multirow{2}{*}{ Trait } & \multicolumn{2}{c}{ Heterosis (\%) over } & \multicolumn{2}{c}{ No. of superior crosses on the base of } \\
\cline { 2 - 5 } & MP & BP & MP & BP \\
\hline Fruit width (cm) & $-32.05-26.79$ & $-34.25-15.46$ & 4 & 3 \\
Fruit length (cm) & $-31.85-53.62$ & $-41.13-27.00$ & 5 & 4 \\
Flesh thickness (cm) & $-39.92-62.06$ & $-34.06-20.80$ & 5 & 4 \\
Cavity diameter (cm) & $-41.59-28.51$ & $-38.79-58.81$ & 9 & 4 \\
TSS & $-12.15-65.31$ & $-16.07-58.82$ & 11 & 9 \\
Ascorbic acid & $9.26-112.36$ & $1.53-107.98$ & 14 & 13 \\
Carotenoids & $11.83-39.09$ & $7.80-35.93$ & 15 & 14 \\
Fruit weight (g) & $-61.62-59.81$ & $-62.27-31.00$ & 8 & 5 \\
Total yield/vine & $-32.99-100.97$ & $-50.65-49.81$ & 9 & 7 \\
Fruit No./vine & $-20.00-100.00$ & $-37.5-69.44$ & 8 & 6 \\
\hline
\end{tabular}

MP : Mid-parent. $\quad$ BP : Better parent 


\section{REFEREANCE}

Briggs, F.N. and P.F. Knowles (1967). Introduction to Plant Breeding, ChapmanReinhold, Inc., USA, 104.

Bhatt, G.M. (1971). Heterosis performance and combining ability in diallel cross among spring wheat ( $T$. aestivum L.). Australian J. Agric. Res., 22: 329-368.

Choudhary, B.R. and S. Pandey (2010). Breeding of $\mathrm{F} 1$ hybrids in muskmelon: Accomplishment and prospects. Indian $\mathrm{J}$. Hort., 5 (1-2): 1-5.

Chadha, M.L. and K.S. Nandpuri (1980). Combining ability studies in muskmelon (Cucumis melo L.) Indian J. Hort., 37 (1): 6265.

Ferreira, M.A.J., L.T. Braz, M.A. QueirOz, M.G.C. Churata-Masca and R. Vencovsky (2002). Capacidade de combinacdo em sete populacoes de melancia. Pesquisa Agropecuaria Brasileira 37: 963-970.

Feyzian, E., H. Dehghani, A.M. Rezai and M.J. Javaran (2009). Diallel cross analysis for maturity and yield-related traits in melon (Cucumis melo L.). Euphytica, 168: 215-223.

Griffing, B. (1956). Concept of general and specific combining ability in relation to diallel crossing system. Australian. J. Biol. Sci., 9: 463-483.

Habeeb (1998). Combining ability and reciprocal effects in $F_{1}$ diallel crosses of soybean (Glycine $\max$ (L.) Merril). J. Agric. Sci. Mansoura Univ., 23 (3): 927-940.

Lohani, M. (2013). Genetic analysis of quantitative traits and molecular characterization of muskmelon on [Cucumis melo L.]. Ph.D., G.B. Pant Agric. and Technol. Univ., India.

Lichtenthaler H.K. and A.R. Wellburn (1985). Determination of total carotenoids and chlorophylls $\mathrm{a}$ and $\mathrm{b}$ of leaf in different solvents. Biochem. Soc. Transactions, 11: 591-592.

Monforte, A.J., M. Oliver, M.J. Gonzalo, J.M. Alvarez and R. Dolcet-Sanjuan (2004). Identification of quantitative trait loci involved in fruit quality traits in melon (Cucumis melo L.). Theoretical and Appl. Genet., 108: 750-758.

Robinson, J.M. and S.J. Britz (2000). Tolerance of a field grown soybean cultivar to elevated ozone level is concurrent with higher leaflet ascorbic acid level, higher ascorbatedehydroascorbate redox status, and long term photosynthetic productivity. Photosynthesis Res., 64 (1): 77-87.

Sadasivam, S. and A. Manickam (1996). Peroxidase Methods in biochemistry, Euphytica, 28 : 108-110.

Singh, M.J. and K.S. Randhawa (1990). Assessment of heterosisand combining ability for quality traits in muskmelon. Indian J. Hort., 47(2): 228-236.

Snedecor, G.W. and W.G. Cochran. (1967). Statistical methods $6^{\text {th }}$ Ed., the Iowa State Univ., Press, Ames, Iowa USA.

Tak, S. (2017). Heterosis, combining ability and stability in interspecific hybrids of cucumis (Doctoral dissertation, MPUAT, Udaipur).

Valerio I.P., F.I.F. Carvalho, A.C. Oliveira, V.Q. Benin, D.A.M. Schmidt, G., Ribeiro, R. Nornberg and H. Luch (2009). Combining ability of wheat genotypes in two models of diallel analyses. Crop Breed. and Appl. Biotechnol., 9:100-107.

Zalapa, J.E., J.E. Staub and J.D. McCreight (2006). Generation means analysis of plant architectural traits and fruit yield in melon. Plant Breed., 125 : 482-487. 


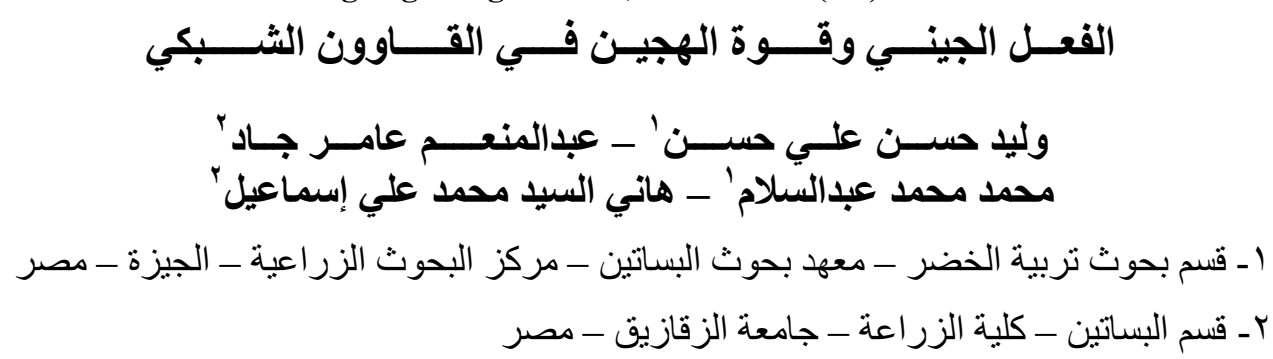

تم استخدام ستة سلالات أبوية من القاوون الثبكي وتسمى: 86E2143 )"673 (P)

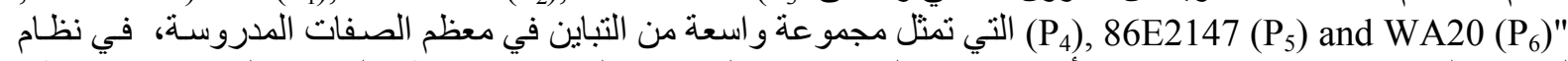

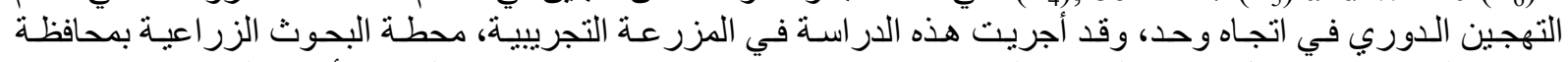

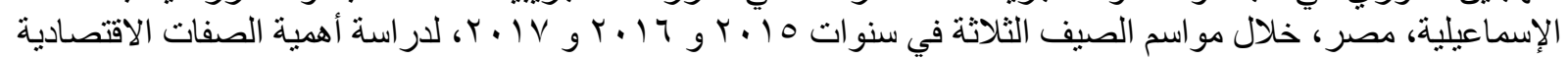

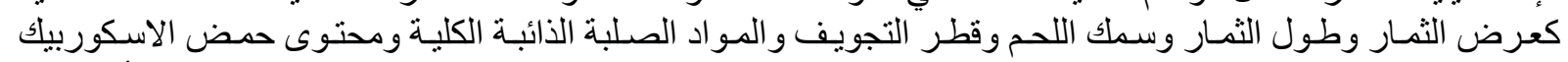

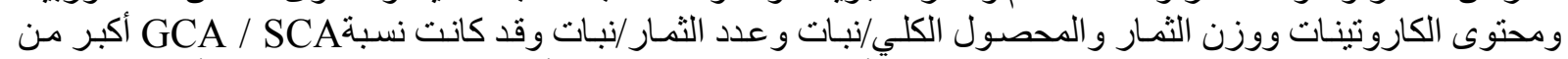

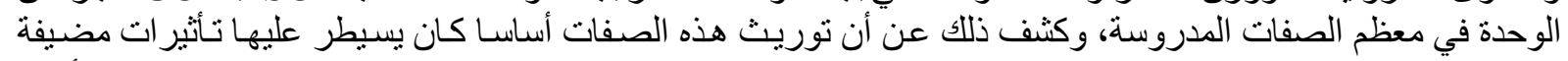

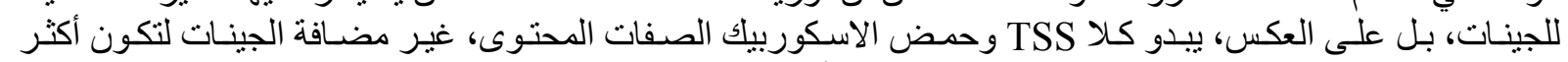

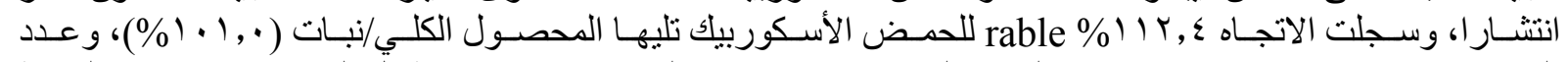

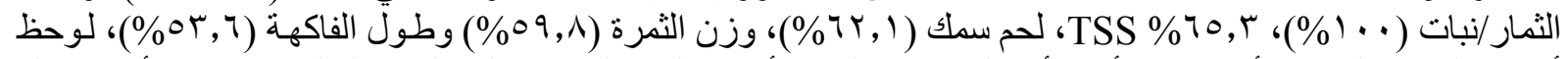

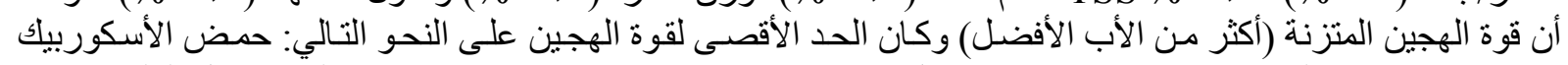

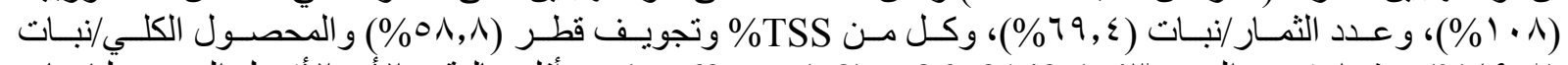

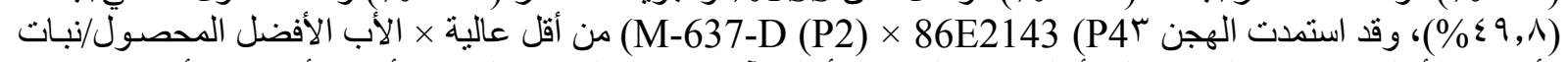

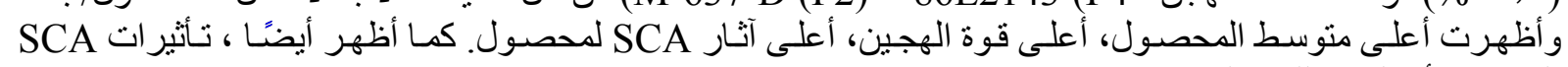
المر غوبة أو الهامة للغاية لثمانية صفات مهمة. 